\title{
A FÖBB SZÁNTÓFÖLDI NÖVÉNYEK STRUKTURÁLIS VÁLTOZÁSÁNAK ALAKULÁSA ÉS JÖVÖBENI KILÁTÁSAI A DÉL-ALFÖLD MEZŐGAZDASÁGÁBAN
}

\author{
Kovács Helga
}

\begin{abstract}
Absztrakt: Magyarország területének mintegy $80 \%$-a termőterület, melynek részét képezi az erdö, nádas, halastó és a mezőgazdasági területek. Az ország különböző részein más-más termelésszerkezet alakult ki a természetföldrajzi adottságoktól és a kulturális tényezőktől függően, ami régiónként eltérő időbeli változásokat mutat. A dolgozat célja annak tanulmányozása, hogy miként változott a DélAlföldön termesztett föbb szántóföldi növények (búza, kukorica, napraforgó és repce) termöterülete és termésátlaga a 2000 és 2019 közötti időszakban. Egyszempontos varianciaanalízist (ANOVA) alkalmaztam annak eldöntésére, hogy a vizsgált szántóföldi növények termőterületeinek részesedése az ország fő régióiban szignifikánsan különbözik-e egymástól. Megvizsgáltam továbbá a búza, a repce, a napraforgó és a kukorica vetésterületének az országosan megmüvelt termőterületekből való részesedése trendjeit. Az elemzéshez a KSH adatbázisait alkalmaztam.
\end{abstract}

\begin{abstract}
About $80 \%$ of the territory of Hungary is arable land, which includes forests, reeds, fishponds and agricultural areas. Different production structures have developed in different parts of the country, depending on the natural geographical features and cultural factors, which show different changes over time. The aim of the study is to analyse how the production area and average yield of the main field crops (wheat, maize, sunflower and rapeseed) grown in the Southern Great Plain change in the period between 2000 and 2019. One-way analysis of variance (ANOVA) was used to determine whether the share of the cultivated areas of the studied field crops in the main regions of the country differed significantly. We also examined trends in the share of wheat, rapeseed, sunflower, and maize acreage in nationally cultivated production areas. The databases of the Central Statistical Office, Hungary were used for the analysis.
\end{abstract}

Kulcsszavak: szántóföldi növények, termőterület, trend, Dél-alföldi régió

Keywords: field crops, production area, trend, Southern Great Plain region

\section{Bevezetés}

Hazánk legfontosabb természeti erőforrása a termőföld. A talajtípusok, a fizikai adottságok, szántóterületek minősége és a domborzati viszonyok kedvezőek a mezőgazdasági termelés számára. Azonban az ország területén jelentős eltéréseket mutatnak a földminőséget befolyásoló tényezők (OTP, 2017). Magyarországon 2019. június 1-jén a földterületek közel 79\%-át kitevő termőterület nagysága 7 millió 319 ezer hektár volt, ami mintegy 36,5 ezer hektárral csökkent az egy évvel korábbi adatokhoz képest. A csökkenés nagy része a szántó müvelési ágból történt területek kivonásával magyarázható. Az ország földterületének 46\%-át művelték szántóként 2019. június 1-jén, ami a korábbi évekhez hasonló adatot mutat (KSH Statisztikai Tükör, 2019). A szántóföldi növények közül a legfontosabbak hazánkban a gabonafélék, hiszen a szántóterületek 55-65\%-át foglalják el. A két legfontosabb szántóföldi növényünk a búza és a kukorica, amelyek hasonló nagyságú - 1-1,2 millió hektár körüli - vetésterületen teremnek. Hazánkban a kukorica vetésterülete kisebb, míg a búzáé nagyobb ingadozásokat mutat. Hosszabb távon e két szántóföldi növény vetésterülete állandónak tekinthető. A vetésterületekkel szemben a 
termésmennyiségek jóval változékonyabbak, ami a termésátlagok ingadozásának köszönhetö. A kukorica termésmennyisége jóval nagyobb ingadozást mutat, mint a búzáé, ami egyértelmủen a kukoricatermesztés nagyobb - elsősorban időjárási kockázatára utal (Csipkés et.al., 2017).

\section{A Dél-alföldi régió természeti földrajzi adottságai}

A Dél-alföldi régió éghajlati- és talajadottságai alapvetően kedvező feltételeket teremtenek a mezőgazdaság számára, azonban a legfontosabb éghajlati elemek (a hőmérséklet és a csapadék) komoly kockázatokat hordozhatnak. A régióban a napi, illetve az évi középhőmérsékleti értékek pozitív és negatív irányban is jelentős kilengéseket mutatnak (Komarek, 2007a). Dél-Baranya mellett itt a legmagasabb az évi napfénytartam Magyarországon. A Dél-Alföld Magyarország egyik legszárazabb területe, így itt az öntözésnek igen fontos szerepe van (Komarek, 2007b, 2007c; Péczely, 2009). A talajviszonyokat tekintve igen változatos a térség, hiszen futóhomok, humuszos talajok, réti csernozjomok, a mészlepedékes csernozjomok, alföldi mészlepedékes csernozjomok, szolonyec réti talajok, réti szolonyecek, sztyeppesedő réti szolonyecek és réti-, réti öntés-, lápos-, valamint réti talajok is előfordulnak a régióban. A változatos talajok miatt a legalacsonyabb és a legmagasabb aranykorona értékủ szántók vegyesen fordulnak elő (Komarek, 2007d). Ennek ellenére a hazai szántóterületek átlagos aranykorona értéke a Dél-alföldi régióban a legmagasabb (1. táblázat).

\section{1. táblázat: A hazai szántóterületek átlagos aranykorona-értéke}

\begin{tabular}{lccccccc}
\hline Régió & $\begin{array}{c}\text { Közép- } \\
\text { Magyarország }\end{array}$ & $\begin{array}{c}\text { Közép- } \\
\text { Dunántúl }\end{array}$ & $\begin{array}{c}\text { Nyugat- } \\
\text { Dunántúl }\end{array}$ & $\begin{array}{c}\text { Dél- } \\
\text { Dunántúl }\end{array}$ & $\begin{array}{c}\text { Észak- } \\
\text { Magyarország }\end{array}$ & $\begin{array}{c}\text { Észak- } \\
\text { Alföld }\end{array}$ & $\begin{array}{c}\text { Dél- } \\
\text { Alföld }\end{array}$ \\
\hline Szántó & 19,7 & 21,5 & 20,6 & 21,4 & 7,7 & 18,7 & 24,4 \\
\hline
\end{tabular}

Forrás: KSH (2008)

A Dél-Alföld természeti adottságai viszonylag heterogének. Az Alföld jellemző sajátosságai a Dél-alföldi régióra is érvényesek. A terület legfontosabb jellemzői a nagy évi és napi hőmérséklet-ingadozás, a csapadékos és az aszályos évek váltakozása, a tavaszi fagy és a nyári szárazság. A mezőgazdasági kultúrák számára a talaj- és éghajlati viszonyok kedvezőek (Stefanovits, 1963; Komarek, 2008).

\section{A Dél-alföldi régió szerepe a szántóföldi növénytermesztésben}

Magyarország területe $93000 \mathrm{~km}^{2}$, melynek mintegy 80\%-a termőterület. 2000-ben 4 499,8 ezer hektár szántóterület volt az ország teljes területét vizsgálva. 2019-re ez a szám lecsökkent 4317,7 ezer hektárra, ami húsz év alatt több mint 4\%-os visszaesést jelent a szántóterületeket illetően hazánk vonatkozásában (2. táblázat). A Dél-alföldi régióban 2000-ben 1024 ezer hektár volt szántóterület, ami folyamatosan csökkent 2015-ig. 2016-tól folyamatosan növekedett, 2019-ben elérte az 1000,4 ezer hektárt, ami azonban még mindig 2,3\%-kal elmarad a 2000-ben mủvelt szánóterületek nagyságától. 
2. táblázat: A szántóföldek területe Magyarországon és a Dél-Alföldön szántóterület müvelési ágra vonatkoztatva, május 31, 2000-2019, ezer hektár

\begin{tabular}{cccc}
\hline \multirow{2}{*}{ Év } & \multicolumn{2}{c}{ szántóterület } & \multirow{2}{*}{$\%$} \\
\cline { 2 - 3 } & Magyarország & Dél-Alföld & \\
\hline 2000 & 4499,8 & 1024 & 22,8 \\
2001 & - & 1025,7 & - \\
2002 & - & 1025,7 & - \\
2003 & 4515,4 & 1028,3 & 22,8 \\
2004 & 4510,3 & 1028,6 & 22,8 \\
2005 & 4513,1 & 1031,4 & 22,9 \\
2006 & 4509,6 & 1029,4 & 22,8 \\
2007 & 4506,1 & 1027,4 & 22,8 \\
2008 & 4502,8 & 1026,1 & 22,8 \\
2009 & 4501,6 & 1023,8 & 22,7 \\
2010 & 4322,1 & 998,6 & 23,1 \\
2011 & 4322,3 & 996,7 & 23,1 \\
2012 & 4323,6 & 996 & 23,0 \\
2013 & 4325,7 & 988,5 & 22,9 \\
2014 & 4331,3 & 987,1 & 22,8 \\
2015 & 4331,7 & 987,1 & 22,8 \\
2016 & 4332,3 & 987,6 & 22,8 \\
2017 & 4334,2 & 989,4 & 22,8 \\
2018 & 4333,6 & 997,1 & 23,0 \\
2019 & 4317,7 & 1000,4 & 23,2 \\
\hline
\end{tabular}

Forrás: KSH (2019) adatai alapján saját szerkesztés

A 2019-ben az összes termőterület közel 40\%-át az Alföldön művelték, amely majdnem egyenlő arányban oszlott meg az Észak- és Dél-Alföld között. A DélDunántúl és Észak-Magyarország (14,2\%-13,8\%), valamint a Nyugat-Dunántúl és Közép-Dunántúl (12,1\%-12\%) részesedése az összes termőterületből közel azonos volt. Budapest és Pest megye földhasználata mindösszesen csupán 8,4\%-ot tesz ki a főváros és a kiépült agglomerációja, az ipar és szolgáltatás túlsúlya miatt (KSH, 2019). A Dél-alföldi és az Észak-alföldi régióban együttesen az összes szántóterület több, mint 40\%-a található (1. ábra).

\section{A föbb szántóföldi növények betakarított területének alakulása}

Vizsgáltam a Dél-Alföldre a négy legfontosabb szántóföldi növény (búza, kukorica, repce, napraforgó) termőterületének a részesedését az összes betakarított területhez képest. A 2000-2019 közötti 20 év során a búza termőterülete ebben a régióban volt a legnagyobb. 2019-ben a búza termőterülete 231463 hektár volt, ami több, mint 22\%-a az összes szántóföldi növény termőterületének az országban (2. ábra). A vetési kedvet befolyásolja az időjárás és a termények ára, ami nagymértékben függ a piacon lévő árumennyiségtől és a készletektől. 2018-ban Magyarországon $1 \mathrm{~kg}$ búzát az egy évvel korábbinál 12\%-kal magasabb áron, 49 forintért vettek át, mely ösztönző hatással bírt a következő év búzavetéseire (KSH Statisztikai Tükör, 2019). 
Az ország összes kukoricaterületének csökkenése megállt az elmúlt években köszönhetően az emelkedő áraknak és a bővülő hazai feldolgozó kapacitásoknak (KSH Statisztikai Tükör, 2019). A vizsgált időszakban a Dél-alföldi régióban volt a kukorica harmadik legnagyobb termőterülete Magyarországon az összes hazai régiót tekintve. 2019-ben a kukorica termőterületének közel 22\%-át e régió adta, megelőzve a Dél-dunántúli régiót (3. ábra).

\section{1. ábra: A földterület használata (2019. június 1.) szántóterület múvelési ágra vonatkoztatva $(\%)$}

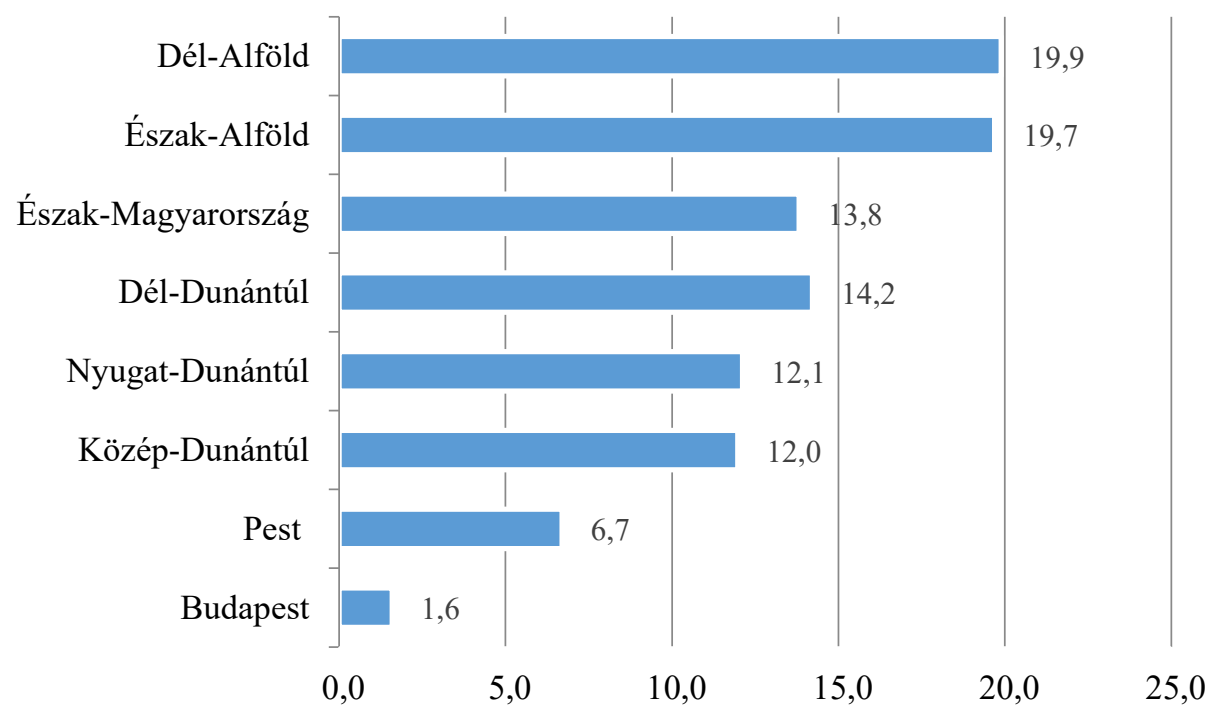

Forrás: KSH (2019) adatai alapján saját szerkesztés

\section{2. ábra: A búza termelése: betakarított terület, hektár}

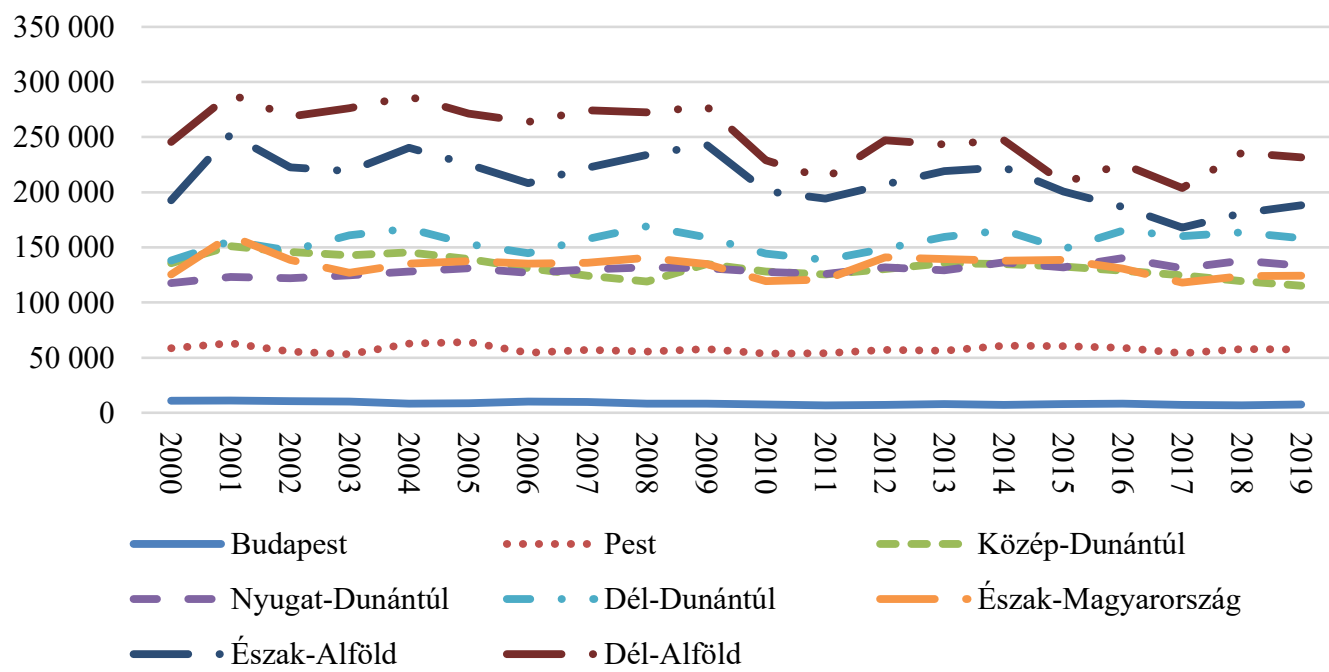

Forrás: KSH (2020) adatai alapján saját szerkesztés 


\section{3. ábra: A kukorica termelése: betakarított terület, hektár}

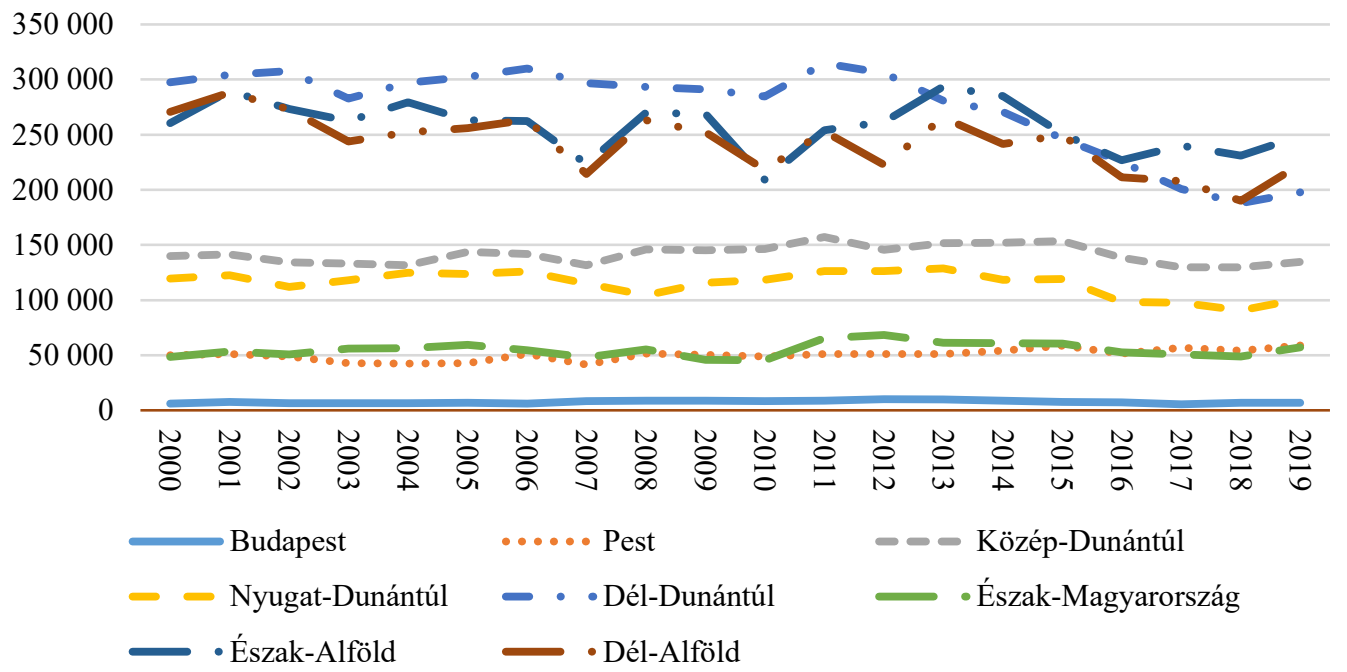

Forrás: KSH (2020) adatai alapján saját szerkesztés

A repce termőterülete 2000 után folyamatosan nőtt. 2018-ban a Dél-alföldi régióban volt a legnagyobb a repce termőterületének aránya, ami az ország repcetermö területeinek közel 18\%-a (4. ábra). A repce termőterülete 2018-ban rekord magas volt, azonban a negyedik legfontosabb szántóföldi növényünknek nem kedvezett a száraz ősz, így hazánkban és a Dél-alföldi régióban is 2019-ben sokkal kisebb területet foglalt el, mint egy évvel korábban (KSH Statisztikai Tükör, 2019).

Hazánkban 2015 és 2017 között a napraforgó vetésterülete több mint harmadával nőtt (KSH Statisztikai Tükör, 2019). A globális kínálat a hazai kínálat bővülésével egyidejüen növekedett, melynek a következménye az lett, hogy nemcsak a Délalföldi régióban, de Magyarországon is csökkent a napraforgó termőterülete. Ennek ellenére a Dél-alföldi régióban a második legnagyobb a napraforgó termőterületének az aránya, csak Észak-Magyarország előzi meg (5. ábra).

A Dél-Alföldet tekintve 2019-ben Békés megyében volt a legnagyobb a búza, kukorica és napraforgó termőterülete, míg Bács-Kiskun megyében a repcét termesztették a legnagyobb területen: 32,8 ezer hektáron (KSH Statisztikai Tükör, 2019).

Megvizsgáltam a főbb szántóföldi növények termőterületének változását a DélAlföldön a 2000-2019 közötti időszakra (6. ábra). Azt tapasztaltam, hogy a repce termőterülete nőtt a legnagyobb mértékben (2,8-szorosára), ugyanakkor a kukorica és a búza termőterülete csökkent, de jóval kisebb mértékben. 


\section{4. ábra: A repcemag termelése: betakarított terület, hektár}

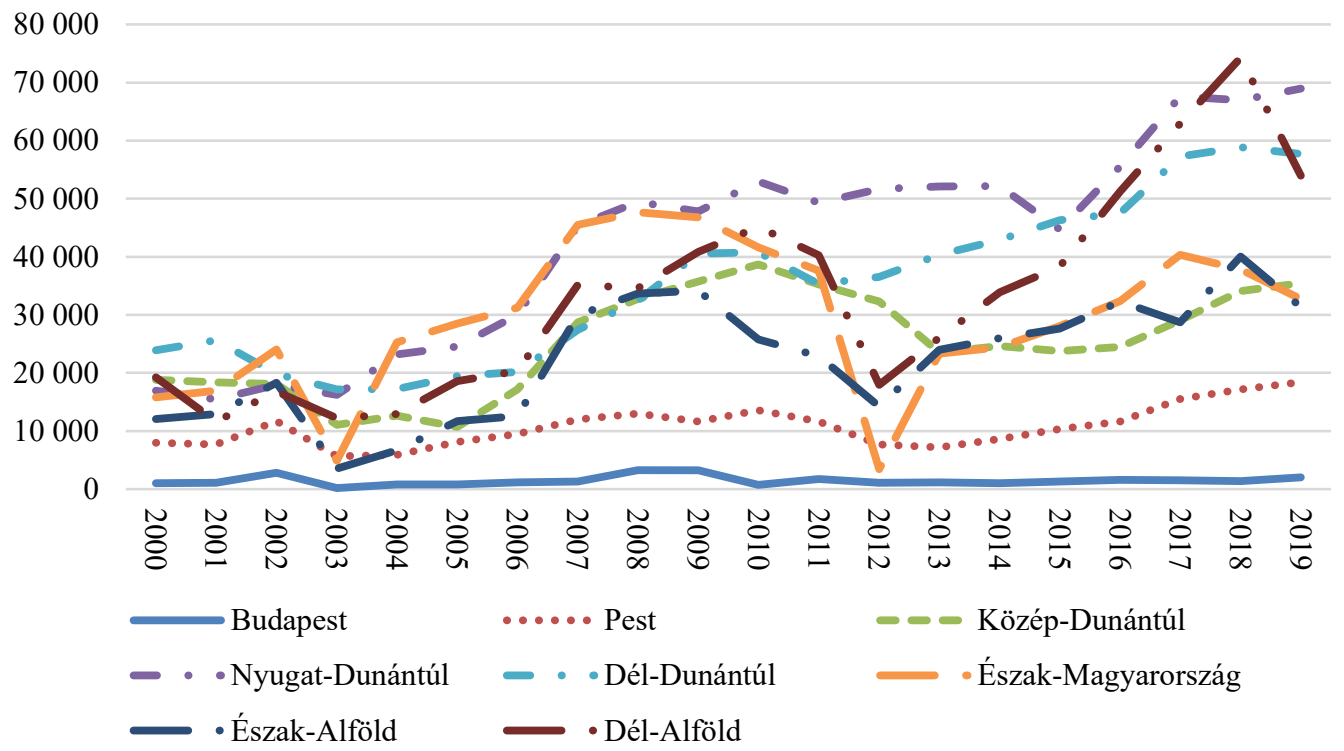

Forrás: KSH (2020) adatai alapján saját szerkesztés

\section{5. ábra: A napraforgómag termelése: betakarított terület, hektár}

250000

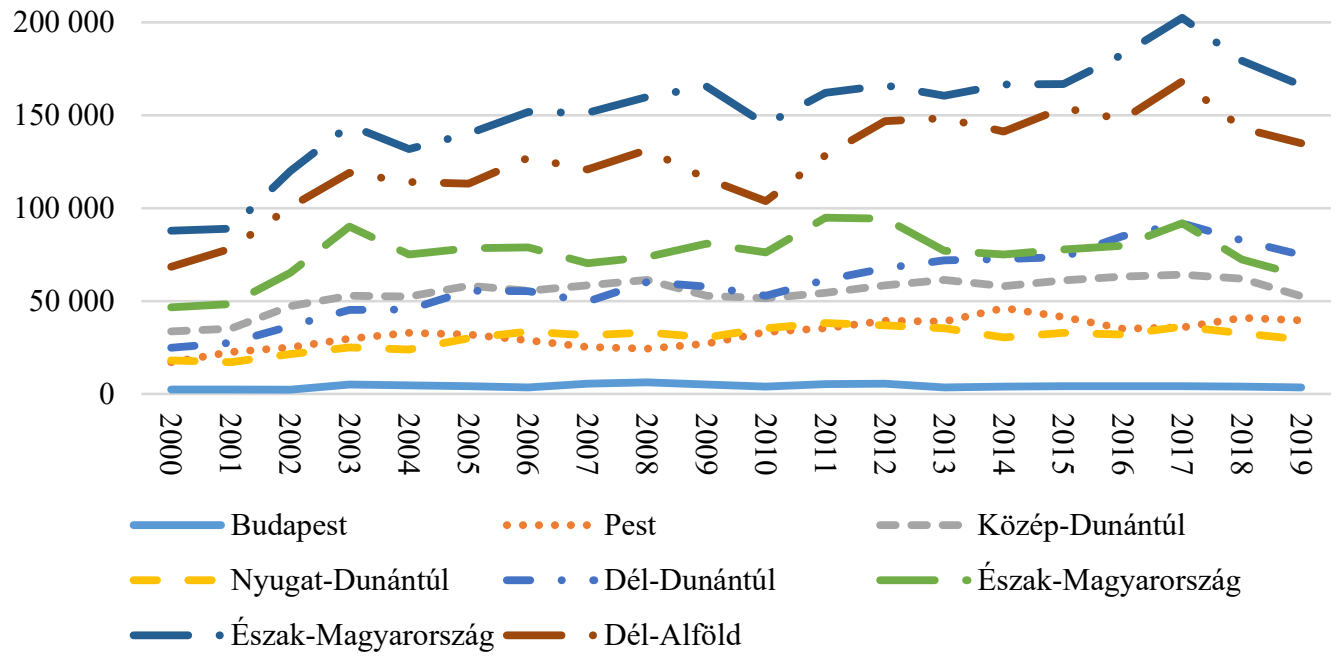

Forrás: KSH (2020) adatai alapján saját szerkesztés 


\section{6. ábra: A szántó és a föbb szántóföldi növények betakarított területének változása a Dél-Alföldön, 2000-2019 (ezer hektár)}

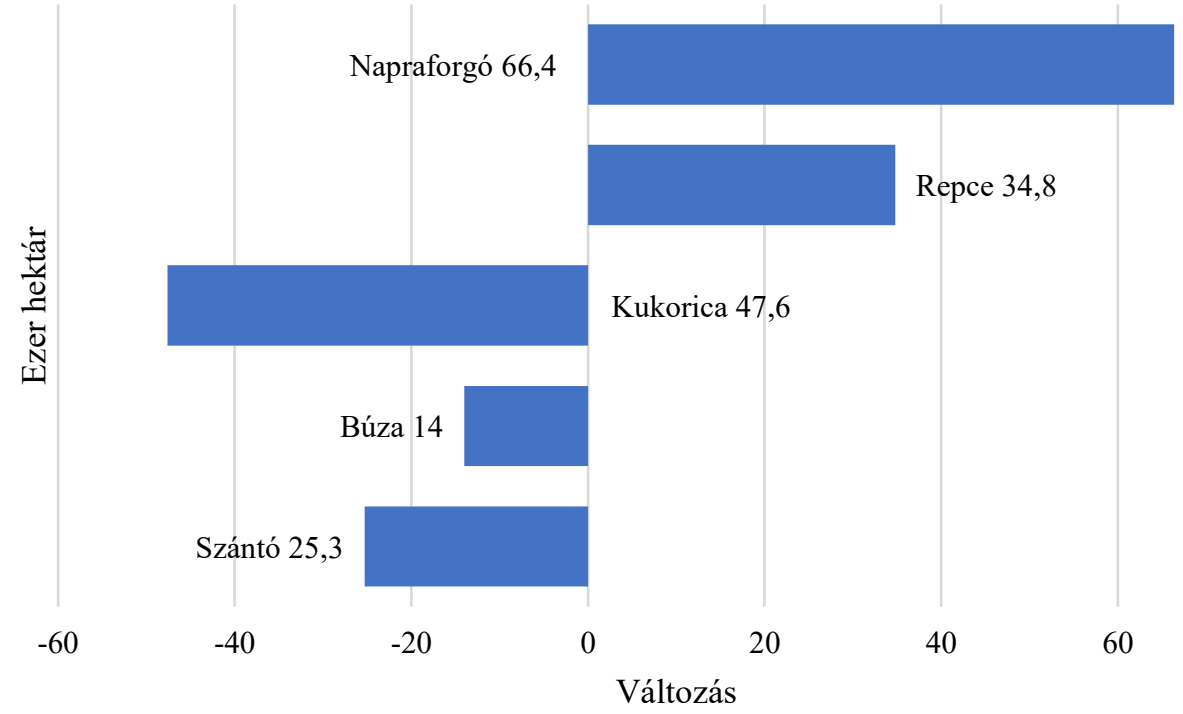

80

Forrás: KSH (2019) adatai alapján saját szerkesztés

\section{A föbb szántóföldi növények termésátlaga a Dél-alföldi régióban}

Megvizsgáltam, hogy miként változott a legfontosabb szántóföldi növények termésátlaga az elmúlt húsz év során (2000-2019) a Dél-alföldi régióban. Az időjárási anomáliák mind a régióban, mind országosan nagy hatással voltak az egyes gabonafélék terméseredményeire. A régióban a búza termésátlaga követte az országos termésátlagot, 2004-ben meg is haladta azt. E tekintetben 2014 volt a leggyengébb év, hiszen ekkor a búza termésátlaga jóval az országos átlag alatt volt. A régióban 2019-ben Békés és Csongrád megyében volt a legalacsonyabb a búza termésátlaga (KSH, 2019: Főbb növénykultúrák terméseredményei). A 2000-2019 közötti időszakban a kukorica hektáronkénti terméshozama alapvetően az időjárás függvényében jelentős ingadozásokat mutatott (KSH, 2019: Főbb növénykultúrák terméseredményei) A Dél-Alföldön a kukorica termésátlaga 2000 és 2019 között csak néhány évben érte el az országos termésátlagot, 2012-ben volt a leggyengébb. A repce termésátlaga 2000 és 2019 között majdnem minden évben megközelítette az országos adatokat. Ebből a szempontból a 2003-as év volt a leggyengébb, míg 2001 a legjobb év. A Dél-Alföldön ebben az időszakban a napraforgó termésátlaga az országos átlag körüli volt és folyamatosan növekedett, 2004-ben pedig kimagasló volt. A négy legnagyobb termelési értékkel rendelkező szántóföldi növény közül a Dél-Alföldön a kukorica termésátlaga marad el a leginkább az országos termésátlagtól. A 2000-2019 közötti időszakban a napraforgó termésátlaga volt a leginkább kiegyensúlyozott mind országosan, mind pedig a Dél-Alföldön. 


\section{Anyag és módszer}

Az egyszempontos varianciaanalízist (ANOVA) alkalmaztam annak eldöntésére, hogy a vizsgált szántóföldi növények (búza, repce, napraforgó és kukorica) vetésterületének részesedése a Dél-Alföldön szignifikánsan különbözik-e a többi régió müvelési arányaitól (Bolla-Krámli, 2012). F-próbát hajtottam végre annak ellenőrzésére, hogy vajon a vizsgált négy szántóföldi növény vetésterületei 20 éves időszakra (2000-2019) vonatkozó régiónkénti részesedéseinek átlagos értékei szignifikánsan eltérnek-e egymástól. Ha az eltérés szignifikáns, akkor az átlagok egyezőségére vonatkozó 0-hipotézist elvetem. Ekkor és csak ekkor alkalmazhatom a Tukey-próbát annak eldöntésére, hogy konkrétan mely szántóföldi növények vetésterületének régiónkénti részesedése között tapasztalható szignifikáns eltérés (Tukey, 1953).

A Tukey-próba jól viselkedik mind az elsőfajú hiba felhalmozódása, mind pedig a próba erőssége szempontjából. (Ha az egyszempontos ANOVA végrehajtásával teljesül a 0-hipotézis, akkor nincs értelme elvégezni a Tukey-próbát.) Amikor elvégzem a post hoc Tukey-próbát, először megkapom a vizsgált négy szántóföldi növény régiónkénti vetésterülete részesedéseinek átlagai közötti eltéréseket. Ezután összevetem ezeket az eltéréseket egy kritikus értékkel azon célból, hogy megállapítsam, vajon ezen eltérések túllépnek-e egy kritikus szintet, azaz szignifikánsak-e.

Ha a vizsgált szántóföldi növények vetésterülete régiónkénti részesedéseinek átlagai közötti eltérések túllépik a küszöbértéket, akkor azt mondhatom, hogy a tényleges eltérés szignifikáns. Amikor a Tukey-próbával összehasonlítottam a vizsgált növények régiónkénti vetésterülete részesedéseinek átlagai közötti eltéréseket, akkor a vetésterületek régiónkénti részesedései páronkénti átlagainak eltéréseiben nemcsak az egyedi hatást (az aktuális két szántóföldi növény hatását), hanem a maradék két növény közös hatását is figyelembe vettem.

A Tukey-próba végrehajtásakor elöször meghatároztam az összes régió összes lehetséges vetésterület-részesedés pár átlagai közötti eltéréseket, majd összevettem őket a következő statisztikával:

$$
H S D=q \sqrt{\frac{M S_{w}}{n}}
$$

ahol $q$ a megfelelő szabadsági fokú studentizált értékkészlet statisztika, melynek aktuális értéke táblázatból kikereshető. $M S w$ a csoporton belüli átlagos négyzetes eltérés, mely az ANOVA végrehajtásakor már ismert, míg $n$ a csoporton belüli mintaelemek száma (Tukey, 1985; Makra et al., 2010, 2011; Matyasovszky et al., 2011; Makra et al., 2013, 2016). 


\section{Eredmények}

Megvizsgáltam a búza, a rece, a napraforgó és a kukorica országos vetésterülete részesedésének a trendjeit, $\mathrm{s}$ azt tapasztaltam, hogy azoknak az országosan megmüvelt termőterületekből való részesedése nem mutat szignifikáns időbeli változást, tehát mindegyik szántóföldi növény tartja a részesedését a vizsgált 20 éves (2000-2019) időszakban (7. ábra).

\section{7. ábra: A vizsgált szántóföldi növények vetésterülete részesedésének trendjei az országosan megmüvelt termőterületekből, 2000-2019, \%}

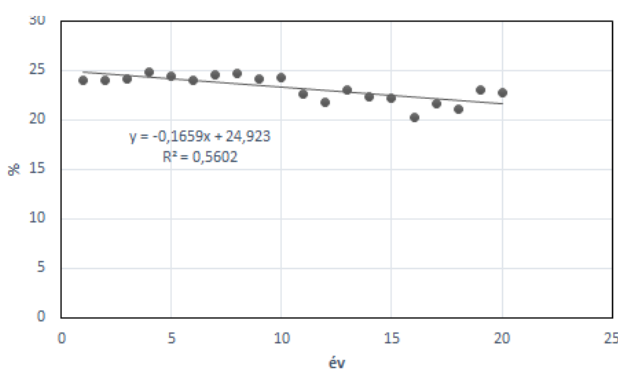

búza

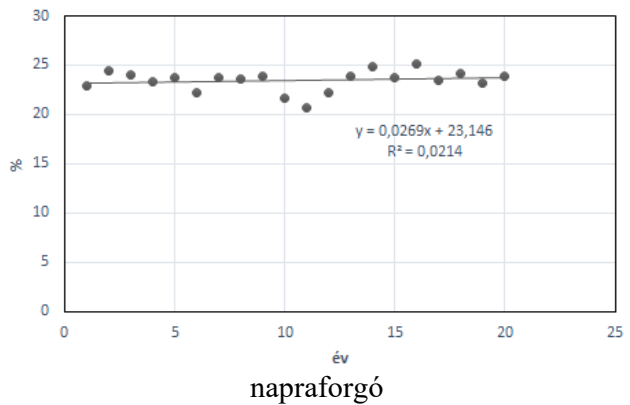

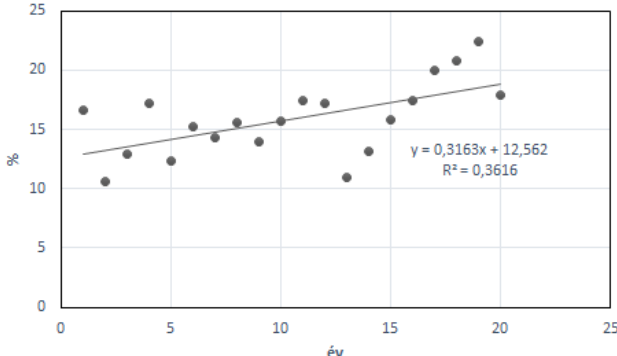

repce

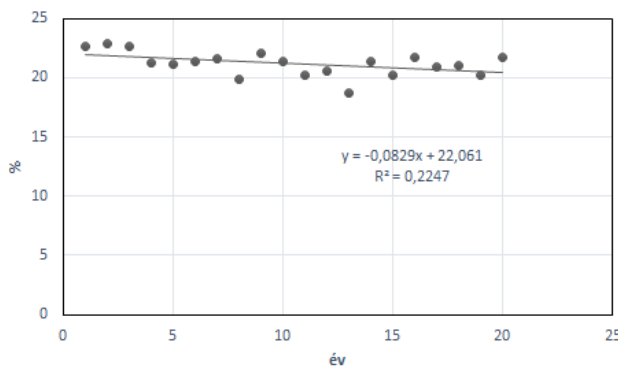

kukorica

Forrás: saját szerkesztés

Összevetettem a föbb szántóföldi növények országos vetésterületeit a vizsgált időszakra, és a százalékos részesedéseik alapján az ANOVA és a Tukey teszt segítségével megállapítottam, hogy a búza és a repce, a búza és a kukorica, a repce és a napraforgó, a repce és a kukorica, valamint a napraforgó és a kukorica vetésterületeinek a kiterjedése országosan szignifikánsan különbözik egymástól, s csupán a búza és a napraforgó vetésterülete nem mutat lényeges eltérést (8. ábra).

A következőkben megvizsgáltam, hogy Magyarország nyolc nagy régiójában (Budapest főváros régió, Pest megye régió, Közép-Dunántúl, Nyugat-Dunántúl, DélDunántúl, Észak-Magyarország, Észak-Alföld és Dél-Alföld) a kiválasztott négy fö szántóföldi növény termésátlagaiban kimutatható-e szignifikáns különbség a 20002019 közötti 20 éves időszak adatai alapján.

Az ANOVA végrehajtásával, majd ezt követően a Tukey teszt segítségével elvégzett páronkénti összehasonlítások alapján a napraforgó és a kukorica termésátlagaiban $(\mathrm{kg} / \mathrm{ha})$ nem mutatható ki szignifikáns különbség az egyes régiók között. Ugyanakkor a búza és a repce régiónkénti termésátlagainak összevetésekor 
találtam szignifikáns különbségeket (9. ábra, 10. ábra). Nevezetesen, a búza esetében Budapest föváros régió és Dél-Dunántúl, Pest megye régió és DélDunántúl, Észak-Magyarország és Dél-Dunántól, valamint Észak-Alföld és DélDunántúl termésátlagai között tapasztalható szignifikáns eltérés. A Dél-Dunántúlon szignifikánsan magasabb a búza termésátlaga, mint a páronkénti összevetésben vele kapcsolatba hozott négy régióban $(8$. ábra). A repce termésátlagai Budapest fóváros régió és Nyugat-Dunántúl, valamint Budapest föváros régió és Dél-Dunántúl páronkénti összevetésében mutatnak szignifikáns eltérést: mindkét esetben a Nyugat-Dunántúl és Dél-Dunántúl termésátlagai szignifikánsan magasabbak (10. ábra).

8. ábra: A vizsgált szántóföldi növények vetésterülete részesedésének összevetése az ANOVA és a Tukey próba alapján, 2000-2019, \% (X: szignifikáns a p <0,01-os valószínüségi szinten)

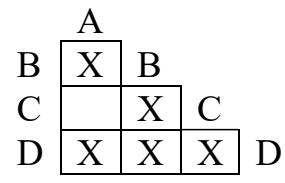

Jelmagyarázat: A: búza; B: repce; C: napraforgó; D: kukorica;

Ezen összehasonlításokból látszik, hogy elsősorban Dél-Dunántúl, de részben Nyugat-Dunántúl is jóval kedvezőbb feltételekkel rendelkeznek a búza és a repce termesztéséhez Budapest főváros régióhoz, és Pest megye régióhoz, továbbá ÉszakMagyarországhoz, és az Észak-Alföldhöz képest.

9. ábra: A búza termésátlagainak összevetése Magyarország nyolc nagy mezőgazdasági régiójában az ANOVA és a Tukey próba alapján, 2000-2019, (kg/ha) (X: szignifikáns a p < 0,01-os valószínúségi szinten)

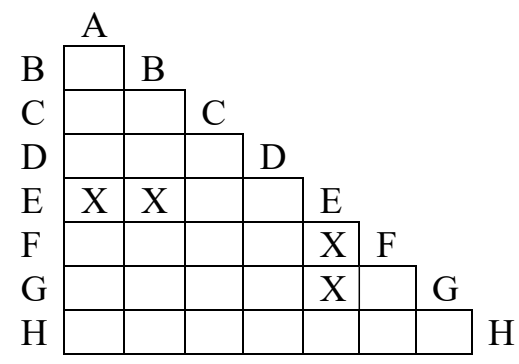

Jelmagyarázat: A: Budapest főváros régió; B: Pest megye régió; C: Közép-Dunántúl;, D: Nyugat-

Dunántúl; E: Dél-Dunántúl; F: Észak-Magyarország; G: Észak-Alföld; H: Dél-Alföld; 
10. ábra: A repce termésátlagainak összevetése Magyarország nyolc nagy mezőgazdasági régiójában az ANOVA és a Tukey próba alapján, 2000-2019, (kg/ha) (X: szignifikáns a p < 0,01-os valószínúségi szinten)

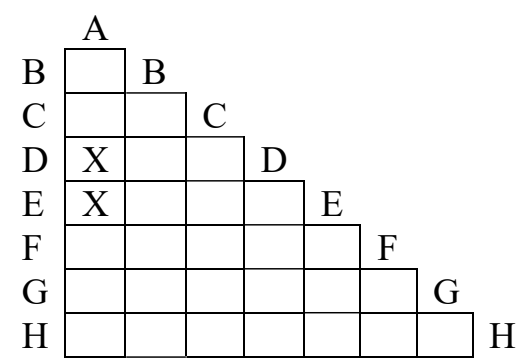

Jelmagyarázat: A: Budapest főváros régió; B: Pest megye régió; C: Közép-Dunántúl;, D: NyugatDunántúl; E: Dél-Dunántúl; F: Észak-Magyarország; G: Észak-Alföld; H: Dél-Alföld;

\section{8. Összefoglalás}

A hazai szántóterületek átlagos aranykorona értéke a Dél-alföldi régióban a legmagasabb és itt a legnagyobb a szántóterületek aránya is az országban. Az itt termesztett négy legfontosabb és legnagyobb termelési értékekkel rendelkező szántóföldi növény a búza, kukorica, repce, és napraforgó. A búza betakarított területe az országoshoz képest a Dél-Alföldön volt a legnagyobb, a második legnagyobb a napraforgó és a kukorica betakarított területek aránya, míg a repce a harmadik helyre csúszott vissza 2019-ben, köszönhetően az előző év száraz őszi időjárásának. A Dél-Alföldön a négy legnagyobb termelési értékkel rendelkező szántóföldi növény az országosan megmüvelt termőterületekből való részesedése jelentős időbeli változást nem mutat, tehát mindegyik szántóföldi növény tartja a részesedését a vizsgált 20 éves (2000-2019) időszakban és várhatóan a jövőben is. Az ANOVA és a Tukey teszt segítségével megállapítottam, hogy csupán a búza és a napraforgó régiónkénti vetésterülete nem mutat számottevő eltérést. A földterület mủvelési ágak szerinti megoszlása 2000 óta nem változott markánsan a DélAlföldön. A legjelentősebb módosulás a repce betakarított területeiben történt: 2,8szorosára nőtt 2019-ben 2000-hez képest.

\section{Köszönetnyilvánítás}

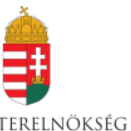

$\mid \begin{aligned} & \text { Nemzeti } \\ & \text { Tehetség Program }\end{aligned}$

MINISZTERELNÖKSÉG

CSALÁdokérT FeLELÖS TÁrCA NÉLKÜLI MINISZTER

\section{Irodalomjegyzék}

Bolla M., Krámli A. (2012): Statisztikai következtetések elmélete. Typotex, Budapest.

Csipkés M., Nagy L., Szabó K. (2017): Magyarország földhasználatának elemzése rendszerváltástól napjainkig. Jelenkori Társadalmi és Gazdasági Folyamatok, 12 (1-2): 141-152.

Komarek L. (2007a): Strukturális változások a Dél-Alföld mezőgazdaságában a rendszerváltozás után (folyamatok és lehetőségek). PhD Értekezés. Szegedi Tudományegyetem, Gazdasági Földrajzi Doktori Iskola, Szeged. 
Komarek L. (2007b): A földhasznosítás rendszerváltozás utáni módosulásai a Dél-Alföldön. In: Kovács Cs. - Pál V. (szerk.) A társadalmi földrajz világai: [Becsei József professzor 70. születésnapjára] Szeged, Magyarország: pp. 325-332.

Komarek L. (2007d): The structural changes in the agriculture of the South Great Plain since the regime change. In: Kovács, Cs. (szerk.): From villages to cyberspace: In commemoration of the 65th birthday of Rezsö Mészáros, Academician: Falvaktól a kibertérig: Ünnepi kötet Mészáros Rezsö akadémikus 65. születésnapjára, Szeged, pp. 329-339.

Komarek L. (2007c): A Dél-Alföldi Régió súlyának, szerepének alakulása a hazai agrártermelésben. Comitatus - Önkormányzati Szemle. pp. 52-64.

Komarek L. (2008): A Dél-Alföld agrárszerkezetének sajátosságai. Csongrád Megyei Agrár Információs Szolgáltató és Oktatásszervező Kht., Szeged.

Központi Statisztikai Hivatal (2008): A mezőgazdaság fejlettségének regionális különbségei. Változások a rendszerváltástól napjainkig. (szerk. Szűcs A.) p. 17. Szeged.

Központi Statisztikai Hivatal (2008): Földterület müvelési ágak szerint (2000-). $<$ http://www.ksh.hu/docs/hun/xstadat/xstadat_eves/i_omf003.html?lang=hu> (2021.02.13.)

Központi Statisztikai Hivatal, (2019): Statisztikai $<$ http://www.ksh.hu/docs/hun/xftp/gyor/vet/vet1906.pdf?lang=hu> (2021.02.20.)

Központi Statisztikai Hivatal (2019): Főbb növénykultúrák terméseredményei, 2019 $<$ https://www.ksh.hu/docs/hun/xftp/stattukor/fobbnoveny/2019/index.html> (2021.02.17.)

Makra L., Ionel, I., Csépe Z., Matyasovszky I., Lontis, N., Popescu, F., Sümeghy Z. (2013): Characterizing and evaluating the role of different transport modes on urban PM10 levels in two European cities using 3D clusters of backward trajectories. Science of the Total Environment, 458-460, 36-46.

Makra L., Matyasovszky I., Guba Z., Karatzas, K., Anttila, P. (2011): Monitoring the long-range transport effects on urban PM10 levels using 3D clusters of backward trajectories. Atmospheric Environment, 45: 2630-2641.

Makra L., Matyasovszky I., Tusnády G., Wang, Y. Q., Csépe Z., Bozóki Z., Nyúl G. L., Erostyák J., Bodnár K., Sümeghy Z., Vogel, H., Pauling, A., Páldy A., Magyar D., Mányoki G., Bergmann, K. C., Bonini, M., Šikoparija, B., Radišić, P., Gehrig, R., Kofol Seliger, A., Stjepanović, B., Rodinkova, V., Prikhodko, A., Maleeva, A., Severova, E., Ščevková, J., Ianovici, N., Peternel, R., Thibaudon, M. (2016): Biogeographical estimates of allergenic pollen transport over regional scales: common ragweed and Szeged, Hungary as a test case. Agricultural and Forest Meteorology, 221: 94-110.

Makra L., Sánta T., Matyasovszky I., Damialis, A., Karatzas, K., Bergmann, K. C., Vokou, D. (2010): Airborne pollen in three European cities: Detection of atmospheric circulation pathways by applying three-dimensional clustering of backward trajectories. Journal of Geophysical Research-Atmosphere, 115: 1-16. D24220.

Matyasovszky I., Makra L., Bálint B., Guba Z., Sümeghy Z. (2011): Multivariate analysis of respiratory problems and their connection with meteorological parameters and the main biological and chemical air pollutants. Atmospheric Environment, 45: 4152-4159.

OTP (2017): OTP Agrár. Javaslat a magyar agrárgazdaság középtávú stratégiájára. OTP Nyrt. Agrárágazati Igazgatósága, Budapest.

Péczely Gy. (2009): Éghajlattan. Nemzeti Tankönyvkiadó, Budapest.

Stefanovits P., 1963: Magyarország talajai. Akadémiai Kiadó, Budapest.

Tukey, J. W. (1953): The problem of multiple comparisons. Unpublished manuscript. In: H.I. Braun (ed.), The Collected Works of John W Tukey VIII. Multiple Comparisons: 1948-1983. Chapman and Hall, New York. pp.1-300. 